\title{
RESPONSE OF THE DANUBE RIVER FLOODPLAIN TO FLOOD EVENTS DURING 2002-2007 PERIOD
}

\author{
Milan LehOTSKÝ, Ján NovotnÝ \\ Slovak Academy of Sciences, Institute of Geography, Bratislava, Slovak Republic \\ JACEK B. SZMAŃDA \\ Jan Kochanowski University, Institute of Geography, Kielce, Poland \\ Manuscript received: June 10, 2010 \\ Revised version: August 1, 2010
}

LehotsKÝ M., Szmańda J.B. \& NovotnÝ J., 2010. Response of the Danube River floodplain to flood events during 2002-2007 period. Quaestiones Geographicae 29(3), Poznań 2010, pp. 37-45, 4 Figs. ISBN 978-83-62662-04-3. ISSN 0137-477X. DOI: 10.2478/v10117-010-0021-6.

АвSTRACT. The relationship between floods and their geomorphic effect is discussed in this article. Almost every flood event is registered in overbank alluvia. We investigated sediment structures and textures as a response to three flood events occurred during 2002-2007 period on the Danube River floodplain in Bratislava. The change in sedimentation is the effect of floodwater flow energy changeability in the channel and floodplain. Generally, three main phases of energy flow changes of floods are recognised and thus the complete flood record can be expressed as the set of three layers. We also analysed conditions of the overbank sedimentation based on the shape and size of sedimented particles. Results show a relatively high variability of sedimentation processes during floods. The total amount of new overbank sediment accumulated in the 2002-2007 period, its texture characteristics and spatial distribution do not depend only on flood discharge, but also on the drainage basin sources of floodwater and sediment.

KEYWORDS: the Danube River, flood record, grain-size data, vertical accretion, floodplain facies

Milan Lehotský, Ján Novotný, Slovak Academy of Sciences, Institute of Geography, Štefánikova 49, 814 73, Bratislava, Slovak Republic, e-mail: geognovo@savba.sk

Jacek B. Szmańda, Jan Kochanowski University, Institute of Geography, Świętokrzyska 15, 25-406 Kielce, Poland, e-mail: j.szmanda@ujk.kielce.pl

\section{Introduction}

River floodplains have attracted increasing attention by hydrologists, geomorphologists, sedimentologists as well as by hydroecologists in recent years. This interest reflects the river's responses to global climatic changes, the ecological significance of floodplains within the landscape, their role as a buffer between the river and the surrounding land, and also a growing awareness of their significance as flood way, sinks or transported sediment and associated nutrients and contaminants. For many lowland river floodplains, particularly those where channelization 
and river training works limit or prevent channel migration, the overbank deposition of fine sediment represents the dominant component of floodplain evolution. In order to develop an improved understanding of this component of floodplain development, more information on patterns and rates of overbank sediment deposition is required. Floodplains that are dominated by vertically accreted fine-grained overbank deposits tend to be relatively flat with particular composition of landforms, typically reflecting the reworking patterns. As a river overflows its banks, it flows in unconfined sheet-like overbank flow with greatly reduced depth and stream power. Cyclical flood couplet deposits reflect the rising and falling stages of floods. Many various kinds of landforms and sets of overbank deposits and their combinations, deposited during flood events, have been described (e.g. Allen 1965, 1970; Brierley 1991; Zwoliński 1992; Miall 1996; Bridge 2003).

Generally, the change in overbank sedimentation is the effect of floodwater flow energy changeability in the channel and floodplain and thus three main phases of energy flow changes (rising, culmination and fall) in one flood event are recognised (Allen 1970) and the complete flood record can be expressed as the set of three layers - three-unit cyclothem, characterizing pensymmetrically graded succession with the coarsest member in the middle part (Mansfield 1938; Klimek 1974). Apart from this, three other kinds of flood flows velocity changes in overbank deposits can be inscribed in sediment records as follows:

The flood rhythm - two layersets or two laminasets (Antczak 1985; Mansfield 1938; Szmańda 2006). Semi-normally graded sequence consisting of two beds (laminae): coarse grained in the bottom and fine grained in the top.

The upward fining Bouma-like structure (Farrell 2001) that is semi-normally graded layerset sequence, similar to Bouma (1962) turbidite current deep-water clastic sediments.

The three-unit cyclothem consisting of lithofacieset (from bottom to top): a horizontally laminated sand (Sh), a ripple cross-laminated (Sr), sand (S) and a massive mud (Fm). Fining upward of grain size can be noticed in this set (Bridge 2003).
Conditions of sedimentation of fluvial lithofacies with given texture and structure properties can be identified by assessing of flow conditions such as flow structure, stream energy, local conditions and processes of channel erosion, transport and deposition of material (Brierley 1991, Miall 1996). Conditions of the fluvial sediment deposition can be also analysed based on the shape and grain size of sedimented particles (e.g. Ruby 1933; Morris 1957; Poole 1957; Braithwaite 1973; Baba \& Komar 1981; McLaren \& Bowles 1985; Ciupa 1991; Mazumder 1994; Le Roux 2002; Ferguson \& Church 2004). The relationship between the initial flow velocities or the velocities when sedimentation is in progress and the grain size can be described by several types of diagrams (for instance: Hjulström 1935; Sundborg 1956, 1967; Cheng 1997; Chien \& Wan 1983; Ferguson \& Church 2004) and several models serve to the estimation of the sedimentation rate on the basis of the mean grain size (e.g. Miller et al. 1977; Koster 1978; Costa 1983; Williams 1983; O'Connor 1993). There are also many inspiring studies dealing with genetic interpretation of sandy fluvial sediments by means of the stream power and flow velocity in dependence on the type of channel bottom landforms and mean grain size (e.g. Allen 1968, Ashley 1990, Southard \& Boguchwall 1990, Chiew 1991, Baas 1994 or Maroulis \& Nanson 1996).

The aim of article is the investigation of sediment structures and textures as a response to three flood events occurred in 2002 and 2007 as well as the interpretation of deposition velocities and conditions of sediment transport relying on results of granulometric analysis of overbank alluvial lithofacies in the Danube River floodplain (inter-dyke area) in Bratislava (Fig. 1). The first flood event happened in the spring 2002 (on $24^{\text {th }}$ of March 2002), and its maximum discharge according to data from the Devín gauge station was $8,474 \mathrm{~m}^{3} \mathrm{~s}^{-1}$. The next flood event with the maximum discharge of $10,370 \mathrm{~m}^{3} \mathrm{~s}^{-1}$ (the Devín gauge station) came in the summer 2002 (on $16^{\text {th }}$ of $\mathrm{Au}$ gust 2002) and it was the second largest flood (according to the magnitude) since 1920 when the hydrological records were introduced. The third, little flood event with the discharge of $7,238 \mathrm{~m}^{3} \mathrm{~s}^{-1}$ (the Devín gauge station) happened on $08^{\text {th }}$ of September 2007. 


\section{Study area}

Lithofacial study of the Danube River overbank deposits was conducted on the right-side inter-dyke inundation area (active floodplain) of 300-600 $\mathrm{m}$ width as unique tectonically deter- mined bench of the Danube River, which is about $5 \mathrm{~km}$ long with the radius of $1.5 \mathrm{~km}$. The area represents a part of the toe of an extensive alluvial fan of the Danube River. Geomorphological and sedimentological research (Novotný et al. 2007) have shown that the old Danube River channel

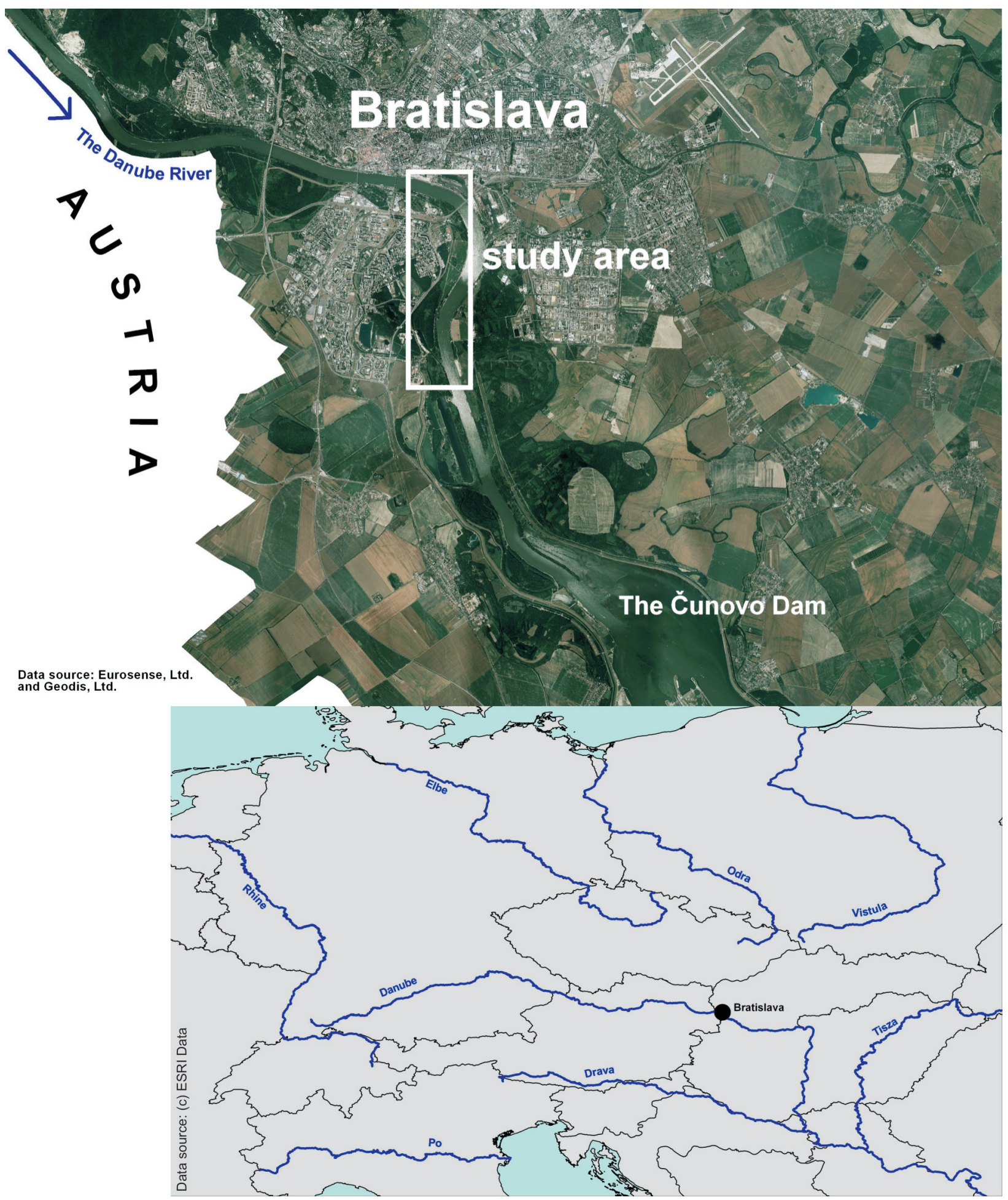

Fig. 1. Location of the study area. 
pattern as well as the alluvium in surroundings of the study area represent an anabranching fluvial system (Wang et al. 2000). The present Danube River valley bottom has been strongly anthropogenically altered in the past. In the $18^{\text {th }}$ to $19^{\text {th }}$ centuries, the river system was reduced to one main channel with the floodplain limited by dykes in order to protect the city against floods (Pišút 2002). The width of the Danube River channel adjacent to the study floodplain is about $350-400 \mathrm{~m}$; the average annual discharge is 2045 $\mathrm{m}^{3} \mathrm{~s}^{-1}$ and the computed 100-year discharge $\mathrm{Q}_{100}$ equal $10000 \mathrm{~m}^{3} \mathrm{~s}^{-1}$ (Svoboda et al. 2000).

\section{Methods}

Borings (10 localities) and pits exposures (20 localities) served as sampling points to determine the processes and rates of the vertical accretion using an allostratigraphic approach classified on the basis of the fluvial style (Miall 1996) and 132 samples were taken for the granulometric analysis. Ten types of lithofacies were discerned in researched flood alluvia of the Danube: 1. massive mud (Fm), 2. massive sandy mud (FSm), 3. massive muddy sand (SFm), 4. horizontally laminated muddy sand (SFh), 5. massive muddy sand with inversed grading (SFmi), 6. massive sand (Sm), 7 . sand with diagonal ripplecross-lamination $(\mathrm{Sr})$, 8. massive gravelly sand (SGm), 9. gravel with compact granular structure $(\mathrm{Gm}), 10$. massive diamicton $(\mathrm{Dm})$. Individual types are discerned by grain-size characteristics and their analysis showed a great variety of deposition conditions (Fig. 2). We have set granular characteristics of samples representing the gravel-sand fraction in interval of 1 phi. The same characteristics were assessed for the sand-mud fraction with interval of 0.25 phi by laser method. We have sorted out analysed samples into individual classes (Udden 1914; Wentworth 1922, Friedman \& Sanders 1978) by means of the Gradistat computer programme (Blott \& Pye 2001). The above-mentioned programme was also used for the computation of textural parameters (Folk \& Ward 1957) as well as of the values of the first percentile (C).
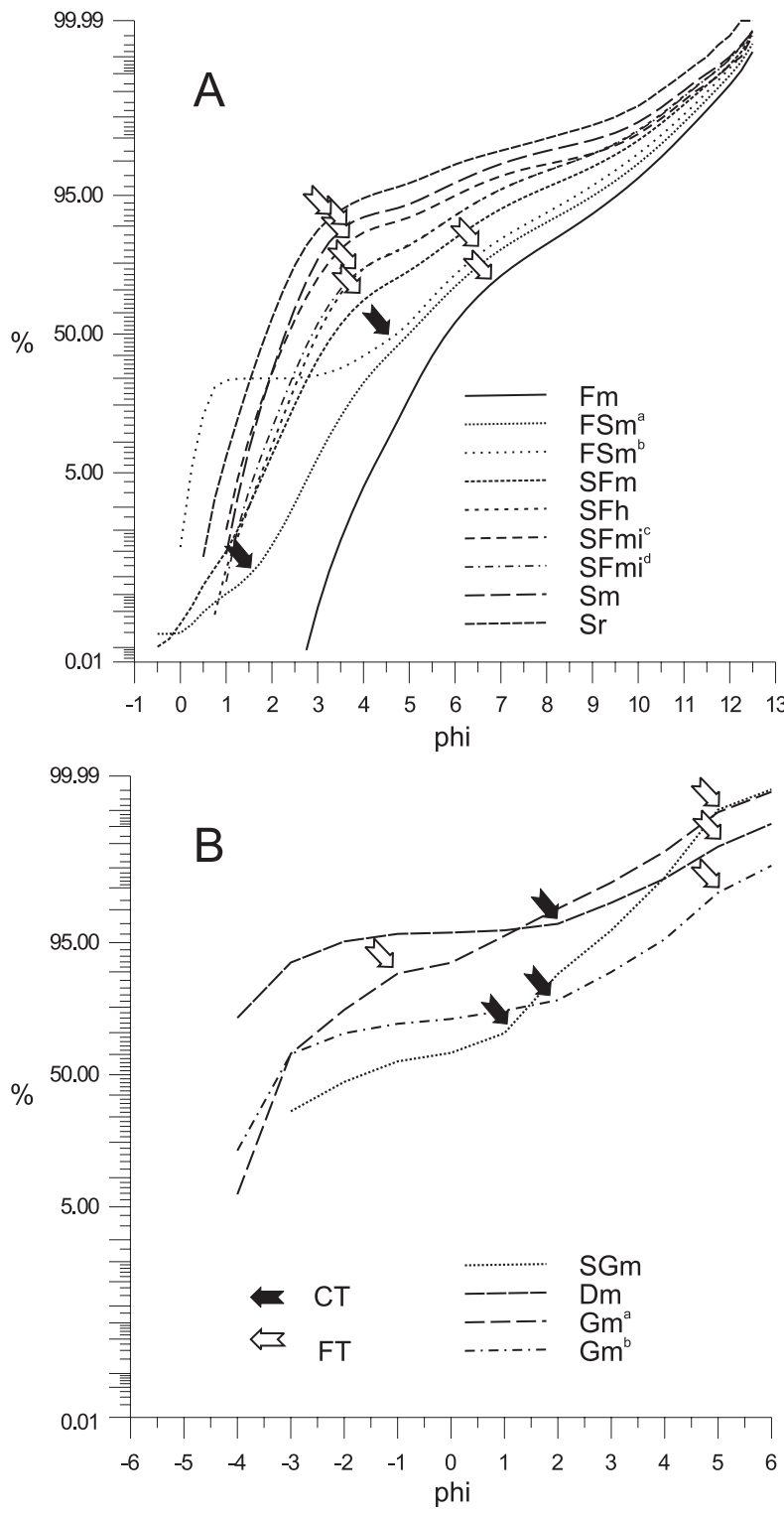

Fig. 2. Grain size composition cumulative curves of Danube river overbank alluvia lithofacies. A - sandy and muddy lithofacies, B - gravelly lithofacies. CT, FT - "break" points

FM - massive mud, FSm - massive sandy mud, SFm - massive muddy sand, SFh - horizontally laminated muddy sand, SFmi - massive inverse grading muddy sand, Sm - massive sand, $\mathrm{Sr}$ - ripple cross-laminated sand, SGm - massive gravelly sand, Gm matrix-supported gravel, $\mathrm{Dm}$ - massive diamicton

a - low energetic subtype, $\mathrm{b}$ - high energetic subtype, $\mathrm{c}$ - top of layer, $\mathrm{d}$ - base of layer 


\section{Results and discussion}

\section{Floodplain vertical accretion during 2002 (March), 2002 (August) and 2007 flood events}

Floodplain vertical accretion and levee formation processes during flood events dominate floodplain evolution of the study floodplain area. According to Allen (1965), levees are best developed on the concave side of bends. Our study suggests that the development of levees proceeds, albeit unusually, in the convex part of the Danube's bend. Levee development can be explained by its limited lateral migration due to the embankment of the left concave bank, which strongly influenced flow direction during floods. Although the convex bankline was shifted (naturally and also by man during the process of artificial channel widening) by $70 \mathrm{~m}$ into the floodplain after the 1997 flood $\left(Q_{10}\right)$, an approximately $50 \mathrm{~m}$ wide strip of overbank sediments was deposited (new levee) in the vicinity of the new bankline after the floods of 2002. This is demonstrated by profile of the new bankline, which is $3 \mathrm{~m}$ above the average annual water level. The basal portion of the bankline consists of gravel horizons overlain by fine sand fractions of new levee. The transition between the channel (gravel) and the floodplain (finer) facies is sharp. The thickness of sand deposits in the upper portion of the bank profile is about one metre suggesting the height of levee deposition. It is possible to observe the sedimentary records of the flood events from 2002 and 2007 in the overbank alluvia mainly in the neighbourhood of the riverbank. The structure of alluvia deposited on the levee by the 2007 flood is shown in Fig. 3. We recognised two three-unit sequences making up the record of three flood phases on this profile. They are deposited above massive silt with isolated pebbles. The similar flood cyclothem of overbank deposits was found on the bank profile (Fig. 4). It is possible to identify three units of different lithofacial features in each of these layer sets:

The lower unit represents an initial; rising phase of flood wave. The lithofacies representing this unit: 1 . the massive sandy silt lithofacies (SFm) of thickness $5 \mathrm{~cm}$ (Fig. 3), 2. the massive inversely graded fine sands - Smi fragment 2-3 $\mathrm{cm}$ thick (Fig. 3), 3. the organic matter layer with

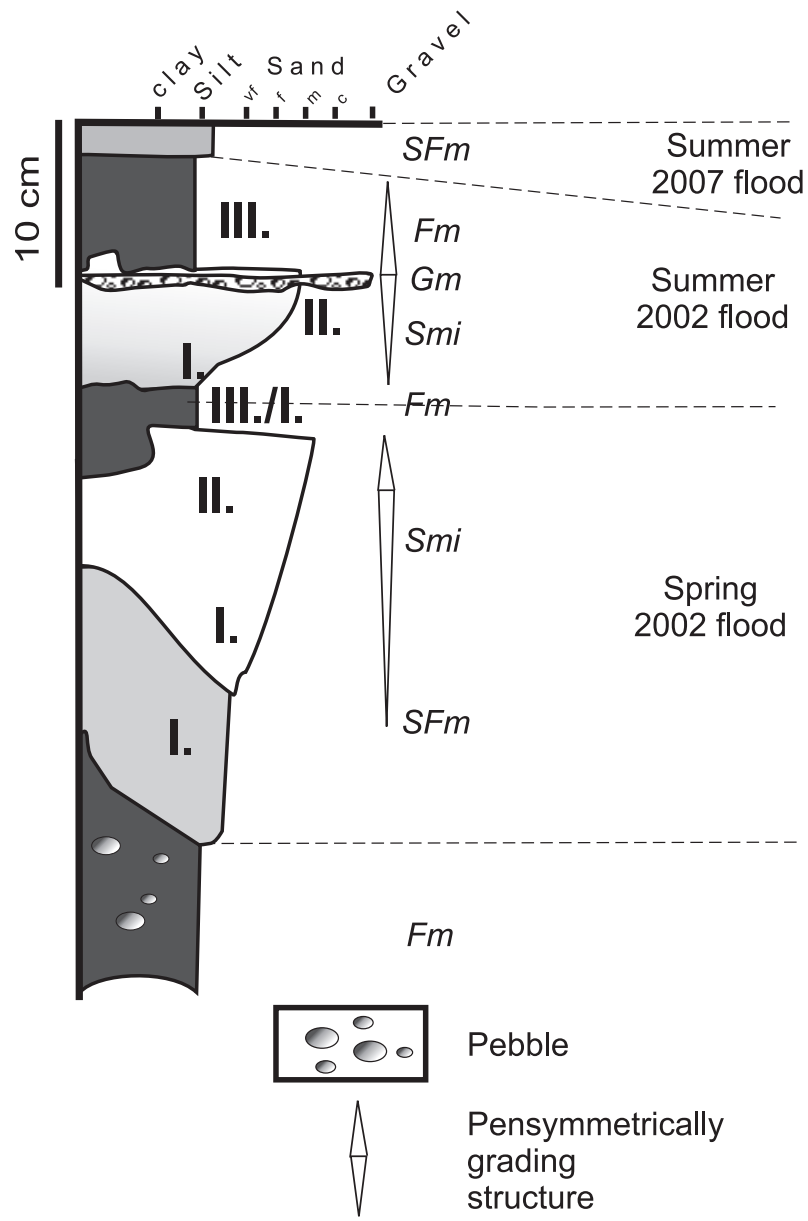

\section{I., II., III. Units of flood cyclothem}

Fig. 3. Overbank alluvia lithofacial profile - natural levee.

the massive silt admixture $(\mathrm{C} / \mathrm{Fm})$ of a few millimetres of thickness (Fig. 4);

The middle unit is recording the phase of widespread of flood water (Allen 1970; Klimek 1974) or "floodplain inundation and initial deposition" and "flood peak and widespread transport and deposition" after Zwoliński (1992) that corresponds with the lithofacies of middle unit of cyclothem. The middle unit is represented by: 1 . the layer of 3-8 $\mathrm{cm}$ thickness of the inversely graded massive fine- and coarse sand lithofacies (Smi) and c.a. layer of $4 \mathrm{~cm}$ thickness of the inversely graded massive coarse sand lithofacies (Smi) associated in roof with the matrix-supported gravel lithofacies $(\mathrm{Gm})$ on the levee sedimentary profile (Fig. 3), 2. the layer of $15 \mathrm{~cm}$ thickness of the subhorizontally and low-angle cross laminated medium sand lithofacies (Sh/Sl) (Fig. 4); 

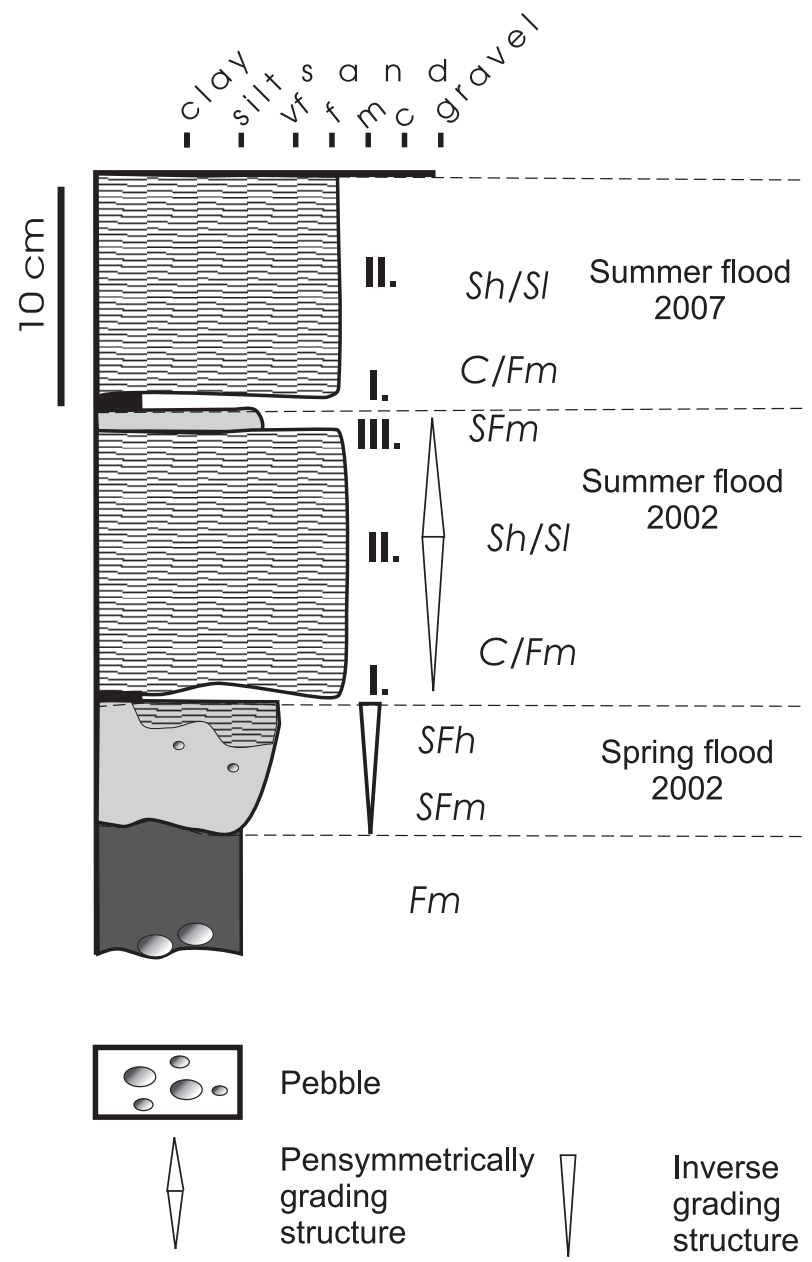

Inverse grading structure

\section{I., II., III. Units of flood cyclothem}

Fig. 4. Overbank alluvia lithofacial profile - channel bank.

The top unit of flood cyclothem is recording the fall of flood wave and clearing of flood basins (Allen 1970; Klimek 1974) or two final phases of flood recognised by Zwoliński (1992). The top unit is represented by: 1 . a few centimetres thick layers of the massive mud lithofacies (Fm) (Fig. 3), 2. a few centimetres thick layers of the massive muddy sand (SFm) lithofacies founded in the profile of bank wall (Fig. 4).

Taking into account the lithofacial features of analysed layersets and their position in profiles, the following correlation between deposits and flood events is assumed:

The 2002 spring flood corresponds to the threeunit flood cyclothem SFm - Smi - Fm found in the levee profile (Fig. 3) as well as the two-unit inversely graded sequence SFm - SFh in the profile of bank wall (Fig. 4).
During the 2002 summer flood, the three-unit flood cyclothem Fm - Smi (Gm) - Fm situated in the levee profile (Fig. 3) as well as the three-unit layerset $\mathrm{C} / \mathrm{Fm}$ - Sh/Sl - SFm in the bank profile (Fig. 4) were deposited. It should be underlined that this sequence is the closest to the three-unit flood cyclothem described by Klimek (1974).

The massive mud (Fm) with organic matter (grass) was accumulated in the rising phase of the 2007 summer flood. Furthermore the horizontally laminated sand and low-angle laminated sand $(\mathrm{Sh} / \mathrm{Sl})$ were deposited in the peak phase of this flood in the profile of bank wall (Fig. 4). Moreover, during this flood a massive muddy sand (SFm) layer of a low thickness was accumulated on the natural levee (Fig. 3).

The 2002 spring flood had less effect at the riverbank (up to $10 \mathrm{~cm}$ of mainly silt) than on natural levee (up to $30 \mathrm{~cm}$ of silt and sand). The 2002 summer flood has more balanced effect (up to 20 $\mathrm{cm}$ of sediments on the bank as well as on natural levee), on the bank mainly horizontally laminated sand, on levee complete flood cyclothem (silt - sand - silt). On the bank the structure of sandy sediments is mainly semi-horizontal lamination and on the levee there is a complete 'flood cyclothem' (three-unit layerset, characterizing pensymmetrically graded sequence: silt - sand - silt). The last flood event (in 2007) afflicted sedimentation mostly in the close vicinity of the bank (up to $10 \mathrm{~cm}$ of sand material), only slight shadows of finer sediment far away from the bank-line could be found. Results show a relatively high variability of sedimentation processes during floods. The total amount of sediments, their texture characteristics and spatial distribution do not depend only on flood discharge, but also on the sources of floodwater and sediments in the river system.

\section{Interpretation of overbank alluvia lithofacies depositional conditions}

Grain-size analysis showed that the composition of the mud lithofacies, sand and gravel lithofacies is unimodal, while that of mud-sand, sandgravel and diamictic ones is bimodal. Individual lithofacies differ each other in grain size and the percentage of individual modal fractions. Values of the basic fractions concur with three main frac- 
tions observed generally in flooding areas (Pettijohn 1957; Spencer 1963) and their content is modified by the deposition environment properties (Folk and Ward 1957; Szmańda 1998, 2004). Energy differentiation of the environment is objectively displayed by the variability of the mean grain size (mean diameter). It means that it is possible to point to the differences in mean deposition velocities of the individual lithofacies, and also within one lithofacies, for instance the massive muddy sand lithofacies with the reversed fractional granularity.

The biggest dimensions of gravels in gravelly lithofacies $(\mathrm{C}=31 \mathrm{~mm})$ indicate high-energetic flood discharges on the Danube floodplain. The minimum flow velocity, necessary for the transport of so big grains exceeds $3 \mathrm{~ms}^{-1}$.

On the contrary, finer gravel lithofacies $(\mathrm{Gm})$ were deposited at a lower energy. In case of the gravel alluvia it is the flow velocity in interval from $11.5 \mathrm{cms}^{-1}$ to $62 \mathrm{cms}^{-1}$. Under such conditions, grains with dimensions from -3 phi to 1 phi accumulate mainly by traction $(79-92 \%$ of all grains). It should be noted though that sediments classified into the same type of the lithofacies might have been deposited in different conditions. For instance, alluvia built by gravel lithofacies with a clast-supported texture $(\mathrm{Gm})$, may have been accumulated at a high share of traction $(80-90 \%)$ and at the flow velocity around $60 \mathrm{cms}^{-1}$, and also under discharges with the lower energy, at flow velocity around $40 \mathrm{cms}^{-1}$, when the share of traction drops to $0 \%$. It is also necessary to mention that the -1 phi sized grains at a higher velocity are deposited from traction while they are accumulated by saltation at a lower velocity (Fig. 2). In other cases of gravel lithofacies (including diamictons), especially grains with perimeter below 5 phi are deposited from saltation while smaller grains are accumulated by suspension. The share of suspension is small (not exceeding 1\%).

Sandy and sand-muddy lithofacies have been deposited from saltation under flow velocity ranging from $1,6 \mathrm{~ms}^{-1}$ to $12,2 \mathrm{~ms}^{-1}$. The transition phase from saltation to suspension occurs when the particle size is from 3.5 phi to 4 phi. These differences are obvious both between the individual lithofacies and within the layers of massive muddy sand with the reverse grading SFmi (Fig.
2). Considering the structural features, the sandy lithofacies of the ripple marks with an average grain size $\mathrm{Mz} 0.27 \mathrm{~mm}$ may be accumulated at velocities from $3.3 \mathrm{cms}^{-1}$ to $12.2 \mathrm{cms}^{-1}$; it means the limit values for the movement of sediments with that grain size (Ashley 1990). Deposition by traction occurs in mud-sandy alluvia but the grain size of sediments accumulated in this way drops to $0.5-1.5$ phi. In case of higher energy flow, the grain size is around $0.5 \mathrm{phi}$, in comparison to 1.5 phi in a lesser flow energy. Moreover, as the interpretation of the mean flow velocity showed, the limit of transfer change from saltation to traction for the grain size of mud-sandy lithofacies exceeding 4 phi appears either at the velocity around $7 \mathrm{cms}^{-1}$ (Koster 1978) or at $1.5 \mathrm{cms}^{-1}$ (O'Connor 1993). Simultaneously, the limit value of the mean grain size when suspension changes into saltation it drops to about 6.5 phi, which is confirmed also by Rees (1966). He observed saltation of silt particles with perimeter around $0.01 \mathrm{~mm}$ at the laboratory. It should be added that the share of saltation of particle grains sized from 2 phi to 6.5 phi in mud-sandy lithofacies accumulated in low-energy conditions reaches the average $80 \%$, while in mud lithofacies this share amounts to the mean $78 \%$. Moreover, ever smaller grains are transported by saltation and the share of saltation slightly drops while share of suspension grows (Fig. 2).

\section{Conclusion}

It is possible to identify and understand individual phases of flood according to the character of overbank deposits. Effect of three floods (two from 2002 and one from 2007) at a part of Danube River floodplain in Bratislava was analysed. This time period is interesting to show formation of a new natural levee as a consequence of marked bank retreat averaged nearly $100 \mathrm{~m}$ during 19492007. The current deposits on the proximal part of the floodplain and of the natural levee differ in texture from the older ones. These differences have been caused by dramatic human influence in last sixty years (e.g. channel widening and deepening, upstream dams construction, floodplain terrain planation). The old deposits are gravelly whereas the current sediment consists 
of fine-grained sands and sandy silts ranging in thickness between $0.5 \mathrm{~m}$ and $1 \mathrm{~m}$. Thin overbank deposits of silt, silty sand and clay up to $0.2 \mathrm{~m}$ thick occur in flat floodplains and on the distal part of the levee. All sampled sites prove that overbank sedimentation occurs mainly in close position to the riverbank and on the natural levee (up to $100 \mathrm{~m}$ from the bank).

The 2002 spring flood has less effect at the bank wall (up to $10 \mathrm{~cm}$ of mainly silt) a bigger on natural levee (up to $30 \mathrm{~cm}$ of silt and sand). The 2002 summer flood has more balanced effect (up to $20 \mathrm{~cm}$ of deposits on the bank wall as well as on natural levee), on the bank wall mainly horizontally laminated sand, on levee the complete flood cyclothem (silt - sand - silt). The last flood event (in 2007) afflicted sedimentation mostly in the close vicinity of the bank (up to $10 \mathrm{~cm}$ of sand material), only slight shadows of finer sediment far away from the bank-line could be found.

Results of grain-size analyses show a relatively high variability of sedimentation processes during floods. The total amount of new sediments, their texture characteristics and spatial distribution do not depend only on flood discharge, but also on the sources of floodwater and sediments in the river system. Independently from the flood flow energy, overbank alluvia were accumulated mainly by saltation and in a distinctly lesser extent by suspension but the particle grain size and the share of grains in individual types of the deposition processes are variable. It was also confirmed that alluvia with lithofacies of massive sandy mud (FSm) and also gravels with the clast-supported texture $(\mathrm{Gm})$, might have been accumulated at a distinctly different share of the individual transport types, while traction alternated with saltation. Besides, deposition by traction only appeared in four subtypes of lithofacies of all thirteen those studied on the floodplain of the Danube River.

\section{Acknowledgements}

The research for this was supported by the Science Grant Agency (VEGA) of the Ministry of Education of the Slovak Republic and the Slovak Academy of Sciences (grant No. 2/0151/09) and by the National Scholarship Programme of the Slovak Republic.

\section{References}

AlLEN J.R.L., 1965. A review of the origin and characteristic of recent alluvial sediments. Sedimentology 5(2): 89-191.

AlLen J.R.L., 1968. The nature and origin of bed-form hierarchies. Sedimentology 10(3): 161-182.

Allen J.R.L., 1970. Physical processes of sedimentation. London, G. Allen \& Unwin University Books: 248 pp.

ANTCZAK B., 1985. Rhythmites on lower terraces of the Warta River, Poland, and their paleohydrologic implications. Questiones Geographicae, Special Issue 1: 31-43.

Ashley G.M., 1990. Classification of large-scale subaqueous bedforms: a new look at an old problem. Journal of Sedimentary Petrology/Journal of Sedimentary Research 60(1): 161-172.

BAAS J.H., 1994. A flume study on the development and equilibrium morphology of current ripples in very fine sand. Sedimentology 41(2): 185-209.

BABA J. \& KOMAR P.D., 1981. Measurement and analysis of settling velocities of natural quartz sand grain. Journal of Sedimentary Petrology/Journal of Sedimentary Research 51(2): 631-640.

Blott S.J. \& Pye K., 2001. GRADISTAT: a grain size distribution and statistics package for the analysis of unconsolidated sediments. Earth Surface Processes and Landforms 26(11): 1237-1248.

Bouma A.H., 1962. Sedimentology of Some Flysch Deposits, A Graphic Approach to Facies Interpretation. Amsterdam, Elsevier: $168 \mathrm{pp}$.

BRAITHWAITE C.J.R., 1973. Settling behaviour related to sieve analysis of skeletal sands. Sedimentology 20(2): 251-262.

Bridge J.S., 2003. Rivers and floodplains, Form, Processes and Sedimentary Record. Oxford, Blackwell Publishing Company: 486 pp.

BRIERLEY G.J., 1991. Floodplain sedimentology of the Squamish River, British Columbia: relevance of element analysis. Sedimentology 38(4): 735-750.

CHENG N.S., 1997. Simplified settling velocity formula for sediment particle. Journal of Hydraulic Engineering 123(2): 149-152.

ChIEN N. \& Wan Z., 1983. Mechanics of Sediment Motion (in Chinese). Beijing, Science Press.

CHIEW Y.M., 1991. Bed features in nonuniform sediments. Journal of Hydraulic Engineering 117(1): 116-120.

CiUpA T., 1991. Wspótczesny transport fluwialny w zlewni Białej Nidy. Kielce: Wydawnictwo Wyżej Szkoły Pedagogicznej im. Jana Kochanowskiego: 156 pp.

Costa J.E., 1983. Paleohydraulic reconstructions of flashflood peaks from boulder deposits in the Colorado Front Range. Geological Society of America Bulletin 94(8): 9861004.

FARRELL K.M., 2001. Geomorphology, facies architecture, and high-resolution, non-marine sequence stratigraphy in avulsion deposits. Cumberland Marshes, Saskatchewan. Sedimentary Geology 139(2): 93-150.

Ferguson R.I. \& CHuRCH M., 2004. A simple universal equation for grain settling velocity. Journal of Sedimentary Research 74(6): 933-937. 
FolK R.L \& WARD W.C., 1957. Brazos River bar [Texas]; a study in the significance of grain size parameters. Journal of Sedimentary Petrology/Journal of Sedimentary Research 27(1): 3-26.

Friedman G.M \& SAnders J.E., 1978. Principles of Sedimentology. New York, Wiley: 792 pp.

HJULSTRÖM F., 1935. Studies of the morphological activity of rivers as illustrated by the river Fyris. University of Uppsala Geological Institute Bulletin 25: 221-557.

KLIMEK K., 1974. The structure and mode of sedimentation of the flood-plane deposits in the Wisłoka valley (South Poland). Studia Geomorphologica Carpatho-Balcanica 8: 136-151.

Koster E.H., 1978. Transverse ribs: their characteristics, origin, and paleohydrologic significance. In Miall A.D. (ed.) Fluvial sedimentology. Canadian Society of Petroleum Geologists Memoir 5: 161-186.

Le Roux J.P., 2002. Shape Entropy and Settling Velocity of Natural Grains. Journal of Sedimentary Research 72(3): 363-366.

MANSField G.R., 1938. Flood deposit of Ohio River January February 1937 - a study of sedimentation. U.S. Geological Survey Water-Supply Paper 838: 693-733.

Maroulis J.C. \& NANSON G.C., 1996. Bedload transport of aggraded muddy from Cooper Creek, central Australia, a flume study. Sedimentology 43(5): 771-790.

MAZUMdER B.S., 1994. Grain size distribution in suspension from bed materials. Sedimentology 41(2): 271-277.

MCLaren P. \& Bowles D., 1985. The effects of sediment transport on grain-size distributions. Journal of Sedimentary Petrology/Journal of Sedimentary Research 55(4): 457-470.

Miall A.D., 1996. The Geology of Fluvial Deposits. Berlin - Heidelberg - New York, Springer-Verlag: 582 pp.

Miller M.C., McCave I.N. \& Komar P.D., 1977. Threshold of sediment motion under unidirectional currents. Sedimentology 24(4): 507- 527.

Morris W.J., 1957. Effects of sphericity, roundness, and velocity on traction transportation of sand grains. Journal of Sedimentary Petrology/Journal of Sedimentary Research 27(1): 27-31.

Novotný J., Lehotský M. \& GrešKovÁ A., 2007. Súčasný morfologický vývoj medzihrádzového priestoru (Dunaj, Bratislava). Geomorphologia Slovaca et Bohemica 7(2): 72-78.

O'CONNOR J.E., 1993. Hydrology, hydraulics, and geomorphology of the Bonneville flood. Geological Society of America Special Paper 274: 83 pp.

Pettionn F. J., 1957. Sedimentary rocks. New York, Harper: 718 pp.

Pišút P., 2002. Channel evolution of the pre-channelized Danube River in Bratislava, Slovakia (1712 - 1886). Earth Surface Processes and Landforms 27(4): 369-390.

Poole D.M., 1957. Size analysis of sand by a sedimentation technique. Journal of Sedimentary Petrology/Journal of Sedimentary Research 27(4): 460-468.
ReEs A.I., 1966. Some flume experiments with a fine silt. Sedimentology 6(3): 209-240.

Ruby W., 1933. Settling velocities of gravel, sand and silt particles. American Journal of Science 25: 325-338.

Southard J.B. \& Boguchwall L.A., 1990. Bed configuration in steady unidirectional water flows; Part 2, Synthesis of flume data. Journal of Sedimentary Petrology/Journal of Sedimentary Research 60(5): 658-679.

SPENCER D.W., 1963. The interpretation of grain size distribution curves of clastic sediments. Journal of Sedimentary Petrology/Journal of Sedimentary Research 33(1): 180-190.

SundBorg A., 1956. The River Klarälven: A Study of Fluvial Processes. Geografiska Annaler 38(2): 125-237.

Sundborg A., 1967. Some Aspects on Fluvial Sediments and Fluvial Morphology I. General Views and Graphic Methods. Geografiska Annaler, Series A, Physical Geography 49A(2-4 Landscape and Processes: Essays in Geomorphology): 333-343.

Svoboda A., Pekárová P. \& Miklánek P., 2000. Flood hydrology of Danube between Devin and Nagymaros. Bratislava: Institute of Hydrology SAS: 96 pp.

SZMAŃDA J.B., 1998. Aluwia wybranych obszarów równin zalewowych Drwęcy i Tążyny w świetle analiz teksturalnych. In Pękala K. (ed.) Gtówne kierunki badań geomorfologicznych w Polsce stan aktualny i perspektywy. Referaty i komunikaty, IV Zjazd Geomorfologów Polskich. Lublin: Wyd. UMCS: 185-190.

SzMAŃDA J.B., 2004. Znaczenie materiału źródłowego i transportu ziaren w akumulacji powodziowej - studium przypadku - aluwia pozakorytowe Wisły, Drwęcy i Tążyny. Prace Geograficzne 200: 355-372.

SZMAŃDA J.B., 2006. Rytmika powodziowa w aluwiach pozakorytowych Wisły, Drwęcy i Tążyny. [Flood rhytmicity in the Vistula, Drwęca and Tążyna rivers valley overbank deposits]. Dokumentacja Geograficzna (Instytut Geografii $i$ Przestrzennego Zagospodarowania, Polska Akademia Nauk) 32: $266-270$.

UdDen J.A., 1914. Mechanical composition of clastic sediments. Geological Society of America Bulletin 25: 655-744.

WANG S., Li J. \& Y IN S., 2000. Basic characteristics and controlling factors of anastomosing fluvial systems. Chinese Geographical Science 10(1): 30-37.

Wentworth C.K., 1922. A Scale of Grade and Class Terms for Clastic Sediments. The Journal of Geology 30(5): 377-392.

Williams G.P., 1983. Paleohydrological Methods and Some Examples from Swedish Fluvial Environments. I. Cobble and Boulder Deposits. Geografiska Annaler. Series A, Physical Geography 65A(3-4): 227-243.

ZWOLIŃSKI Z., 1992. Sedimentology and geomorphology of overbank flows on meandering river floodplains. Geomorphology 4(6): 367-379. 